\title{
Effect of pH-shifting method on solubility and emulsifying properties of soy protein concentrate
}

\author{
PH-değişim metodunun soya protein konsantresinin çözünürlüğü ve emülsiyon \\ özellikleri üzerine etkisi
}

\author{
Gülçin YILDIZ ${ }^{1 *}$ iD \\ ${ }^{1}$ Igdir University, Faculty of Engineering, Food Engineering Department, Iğdır, Turkey
}

\section{To cite this article:}

Yıldız, G. (2019). Effect of pHshifting method on solubility and emulsifying properties of soy protein concentrate. Harran Tarım ve Gıda Bilimleri Dergisi, 23(2):159-166. DOI: $10.29050 /$ harranziraat. 427438

Address for Correspondence: Gül/çin YILDIZ

e-mail:

gulcn86@gmail.com

Received Date:

26.05.2018

Accepted Date:

26.10.2018

\section{ABSTRACT}

The purpose of the current study was to investigate the influence of $\mathrm{pH}$ shifting process on soy protein concentrate to improve its functional properties. In this work, $\mathrm{pH}$ of the soy protein concentrate was adjusted to $\mathrm{pH} 2,3,4,10,11$, and 12 prior to neutral $\mathrm{pH}$ $(\mathrm{pH}$ 7). $\mathrm{pH}$-shifting process effectively improved the solubility of soy protein concentrate, whereas the modification of the samples with the acidic conditions was less pronounced. The alkaline $\mathrm{pH}$ values $(\mathrm{pH} 10,11$, and 12$)$ showed higher solubility

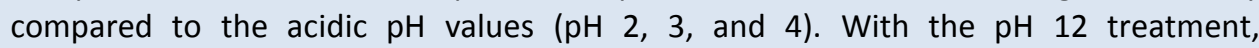
approximately 30 times higher solubility was achieved. Among the treatments, the $\mathrm{pH}$ 12- treated samples showed the improved emulsifying properties with the highest emulsifying activity and stability indexes. All $\mathrm{pH}$ treated samples $(\mathrm{pH} 2,3,4,10,11,12)$ showed less turbidity with smaller particle sizes where the untreated samples showed most turbid structure with the biggest particle size.

Key Words: pH-shifting, Solubility, Soy protein concentrate, Emulsifying properties, Particle size

Öz

Bu çalışmanın amacı, pH değişiminin soya protein konsantresinin fonksiyonel özelliğini artırmaya yönelik etkisini araştırmaktır. Bu çalışmada, soya protein konsantresinin $\mathrm{pH}$ değeri, nötr $\mathrm{pH}$ (pH 7)'dan önce sırasıyla pH 2, 3, 4, 5, 10, 11, ve 12'ye ayarlanmıştır. pHdeğişim işlemi, soya protein konsantresinin çözünürlüğünü etkili bir şekilde artırırken, bu artış asidik koşullar altında muamele edilen numunelerde daha az gözlenmiştir. Alkalin $\mathrm{pH}$ değerleri ( $\mathrm{pH} \mathrm{10,11}$ ve 12), asidik $\mathrm{pH}$ değerlerine $(\mathrm{pH} 2,3$ ve 4) kıyasla daha yüksek çözünürlük göstermiştir. pH 12 ile muamele edilen örneklerde yaklaşık 30 kat daha fazla çözunürlük elde edilmiştir. Örnekler arasında, pH 12 ile muamele edilen numuneler en yuksek emülsiyon aktivite ve stabilite değerlerini göstermişlerdir. Farklı pH değerleriyle muamele edilen örneklerin hepsi, asidik veya alkalin olmasına bakılmaksızın, kontrol örneklerine kıyasla daha küçük parçacık boyutu ve daha az bir bulanıklık sergilemişlerdir.

Anahtar Kelimeler: pH değişim, Çözünürlük, Soya protein konsantresi, Emülsiyon özellikleri, Parçacık boyutu

\section{Introduction}

Soy protein concentrate is a soy product containing at least $65 \%$ protein but less than $90 \%$ protein. Soy protein concentrates are produced by removing soluble sugars, ash, and minor components from the $50 \%$ protein soy flour starting material. The protein is insolubilized, and soluble components are washed out (Campbell et al., 1985). Even though there is an increasing 
demand in using soy proteins due to various advantages in comparison with the other proteins such as high nutritional value, steady supply, and low cost in recent years, soy proteins as emulsifiers are usually reported to be less effective in comparison with other food proteins, such as casein (Santiago et al., 1998). This might be because of the compact globular structures of soy proteins that stabilized basically by hydrogen and disulfide bonds (Palazolo et al., 2005).

Several methods have been developed in order to change the native structure of soy proteins to enhance the functionality. Modified soy protein concentrates demonstrate a very high degree of functionality. Through mechanical and/or chemical modifications it is possible to rearrange protein molecules so that they are more functional. A modified soy protein concentrate described by Howard et al. (1980) showed an increase in its water solubility. This product exhibited improved functionality in various meat systems which was better than compared to soy protein isolates (Moore et al., 1980), and so it might be replaced with milk proteins at lower cost in several applications (Morris, 1980). pH-shifting method, a chemical treatment, fixes the $\mathrm{pH}$ of a protein to extreme values such as $\mathrm{pH} 2$ or $\mathrm{pH} 12$ to unfold the protein, and after that changes the $\mathrm{pH}$ back to neutral to refold the protein This unfolding-refolding step has been announced to modify the protein functional properties powerfully (Jiang et al., 2010, Lee et al., 2016, Yildiz et al., 2017). An improved charge repulsion forces the proteins to a partially unfolded state (Kristinsson et al., 2003). Several studies have reported that globular proteins might be partially unfolded at extreme $\mathrm{pH}$ values, mostly at low $\mathrm{pH}$ levels. This dynamic structure is specified as the "molten globule" (MG) structure (Goto et al., 1989; Goto et al., 1990). This structure maintains a firm structure such as retention of most secondary structure, however has a tendency to lose some of the tertiary structure (Goto et al., 1990). Studies have used myosin (Kristinsson et al., 2003), egg albumin (Liang et al., 2007), and hemoglobin (Kristinsson et al.,, 2004) and exposed them to extreme $\mathrm{pH}$ levels $(\mathrm{pH} 2$ or $\mathrm{pH}$ 12) followed by readjustment of the $\mathrm{pH}$ back to $\mathrm{pH} 7$, called as $\mathrm{pH}$ shifting, to produce MG state proteins. In the MG state, proteins show enhanced functional properties, especially emulsifying and foaming activities. The term " $\mathrm{pH}$ shifting" was reported by Choi et al. (2005) at first to improve the recovery of fish protein from frozen fishes. First of all, they exposed the fish muscle protein to intense $\mathrm{pH}$ values for the water solubility improvement, then the protein was adjusted to $\mathrm{pH}$ 7. The research ensured that the $\mathrm{pH}$ shifting- treated fish protein has outstanding gel-forming ability.

By considering the effectiveness of $\mathrm{pH}$-shifting technique on protein structure by unfoldingrefolding mechanism, it is expected to achieve improved SPC functionality by using $\mathrm{pH}$-shifting. Therefore, the aim of this study is to investigate the effect of $\mathrm{pH}$-shifting treatment on the solubility and emulsifying properties of soy protein concentrate.

\section{Materials-Methods}

\section{Soy protein concentrate (SPC)}

Soy protein concentrate (SPC, Acron SM) was supplied from Archer Daniels Midland (IL, USA). The Acron SM consists of $69 \%$ soy protein on dry base. All chemicals were bought from SigmaAldrich (St. Louis, MO, USA), and Fisher Scientific (Pittsburgh, PA, USA).

\section{pH-shifting process}

Six $\mathrm{pH}$-treatments were applied to modify SPC (Table 1). pH-shifting treatment was applied to SPC solution by following the method proposed by Jiang et al. (2014) with slight modification. SPC dispersion ( $3 \mathrm{~g} 100 \mathrm{~mL}^{-1}$ ) was mixed at room temperature (RT) during half an hour, and later adjusted to $\mathrm{pH} 2,3,4,10,11$ or 12 with $2 \mathrm{M} \mathrm{NaOH}$ or $2 \mathrm{M} \mathrm{HCl}$ at $\mathrm{RT}$. The protein solution was kept at RT during an hour prior to adjust $\mathrm{pH}$ back to neutral. Supernatant was obtained after centrifugation step $\left(8610 \mathrm{rpm}, 20^{\circ} \mathrm{C}\right.$, and $15 \mathrm{~min}$ ) and put in a refrigerator at $4^{\circ} \mathrm{C}$ before the 
analysis. Samples treated with different $\mathrm{pH}$ values were labeled as pH 2, pH 3, pH 4, or pH 10, pH 11, and $\mathrm{pH} 12$, subsequently. For the control samples, $3 \mathrm{~g}$ of SPC without any $\mathrm{pH}$ changes was only stirred in $100 \mathrm{~mL}$ distilled (DI) water during half an hour at RT. Figure 1 shows the preparation of SPC samples.

Table 1. Treatments used to modify soy protein concentrate (SPC)

Çizelge 1. Soy protein konsantresini modifiye etmede kullanılan yöntemler

\begin{tabular}{|c|c|c|c|c|c|c|c|c|c|}
\hline $\begin{array}{l}\text { Treatment } \\
\text { Yöntemler }\end{array}$ & $\mathrm{pH} 2$ & $\mathrm{pH} 3$ & $\mathrm{pH} 4$ & $\begin{array}{l}\mathrm{pH} \\
10\end{array}$ & $\begin{array}{l}\mathrm{pH} \\
11\end{array}$ & $\begin{array}{l}\mathrm{pH} \\
12\end{array}$ & $\begin{array}{l}\text { RT for } 1 \mathrm{~h} \\
1 \text { saat oda } \\
\text { sıcaklığı }\end{array}$ & $\begin{array}{l}\mathrm{pH} \text { adjustment }(\mathrm{pH} 7) \\
\mathrm{pH} \text { ayarlama } \\
(\mathrm{pH} 7)\end{array}$ & $\begin{array}{l}\text { Centrifuge } \\
\text { Santrifüj }\end{array}$ \\
\hline $\begin{array}{l}\text { Control } \\
\text { Kontrol }\end{array}$ & 2 & 2 & 2 & 2 & 2 & 2 & 2 & 2 & 2 \\
\hline $\begin{array}{l}\text { pH-shifting }(\mathrm{pH} 2) \\
\mathrm{pH} \text { değişimi }(\mathrm{pH} 2)\end{array}$ & 1 & 2 & 2 & 2 & 2 & 2 & 1 & 1 & 1 \\
\hline $\begin{array}{l}\text { pH-shifting ( } \mathrm{pH} 3) \\
\text { pH değişimi (pH 3) }\end{array}$ & 2 & 1 & 2 & 2 & 2 & 2 & 1 & 1 & 1 \\
\hline $\begin{array}{l}\text { pH-shifting (pH 4) } \\
\text { pH değişimi (pH 4) }\end{array}$ & 2 & 2 & 1 & 2 & 2 & 2 & 1 & 1 & 1 \\
\hline $\begin{array}{l}\mathrm{pH} \text {-shifting ( } \mathrm{pH} 10) \\
\mathrm{pH} \text { değişimi }(\mathrm{pH} 10)\end{array}$ & 2 & 2 & 2 & 1 & 2 & 2 & 1 & 1 & 1 \\
\hline $\begin{array}{l}\mathrm{pH} \text {-shifting ( } \mathrm{pH} \text { 11) } \\
\mathrm{pH} \text { değişimi (pH 11) }\end{array}$ & 2 & 2 & 2 & 2 & 1 & 2 & 1 & 1 & 1 \\
\hline $\begin{array}{l}\text { pH-shifting ( } \mathrm{pH} 12) \\
\mathrm{pH} \text { değişimi (pH 12) }\end{array}$ & 2 & 2 & 2 & 2 & 2 & 1 & 1 & 1 & 1 \\
\hline
\end{tabular}

(RT: Room temperature storage; 1: shows the steps applied for the treatment; and 2: shows the steps that were not applied for the treatment)

(RT: Oda sıcaklığı, 1: işlem sırasında uygulanan basamaklar; ve 2: işlem sırasında uygulanmayan basamaklar)

\section{Solubility}

Solubility of the samples was measured with a Bio-Rad Protein Assay based on the method described by Bradford (1976). Bovine serum albumin (BSA) was used as the standard. Dye reagent was prepared by diluting 1 part of dye reagent concentrate into 4 parts of DI water, and filtered through a filter paper. This dilution was mixed with soluble SPC. Protein concentration of soluble SPC was measured by spectrophotometer at the wavelength of $595 \mathrm{~nm}$. Protein solubility was calculated as below and expressed as "\%":

Recovery of soluble protein $(\%)=\frac{\text { Protein concentration in soluble SPC }}{\text { Initial protein concentration }} \times 100$

\section{Surface hydrophobicity}

Surface hydrophobicity (Ho) of SPC dispersions was measured by following the method of Yildiz et al. (2017). 1-anilino-8-naphthalenesulfonate (ANS) was used as the fluorescence probe. ANS stock solution ( $8 \mathrm{mM}$ ) was prepared in phosphate buffer (0.01 M, pH 7). Similarly, different soy protein concentrations, changes from 0.04 to 0.2 $\mathrm{mg} \mathrm{mL}^{-1}$, were prepared with same phosphate buffer (0.01 M, pH 7). ANS stock solution (20 $\mu \mathrm{L})$ was mixed with protein solutions and the intensity was measured at $340 \mathrm{~nm}$ (excitation) and $440 \mathrm{~nm}$ (emission). The slope of fluorescence intensity vs. protein concentration were calculated and referred as $\mathrm{H}_{0}$ of proteins.

\section{Free sulfhydryl groups}

Free sulfhydryl groups (Free-SH) were measured as proposed by Lee et al. (2016). A cysteine hydrochloride monohydrate (changing from 0 to $1.5 \mathrm{Mm}$ ) was dissolved in a sodium phosphate buffer (0.1. M). $50 \mu \mathrm{L}$ of Ellman's reagent solution was added in the mix which consist of $250 \mu \mathrm{L}$ of protein sample and $2.5 \mathrm{ml}$ of sodium phosphate buffer. The solution was wellmixed and after incubation at RT for $15 \mathrm{~min}$, the absorbance at $412 \mathrm{~nm}$ was measured. The free $\mathrm{SH}$ content of SPC samples was expressed as $\mu \mathrm{mol} \mathrm{g}^{-1}$ 


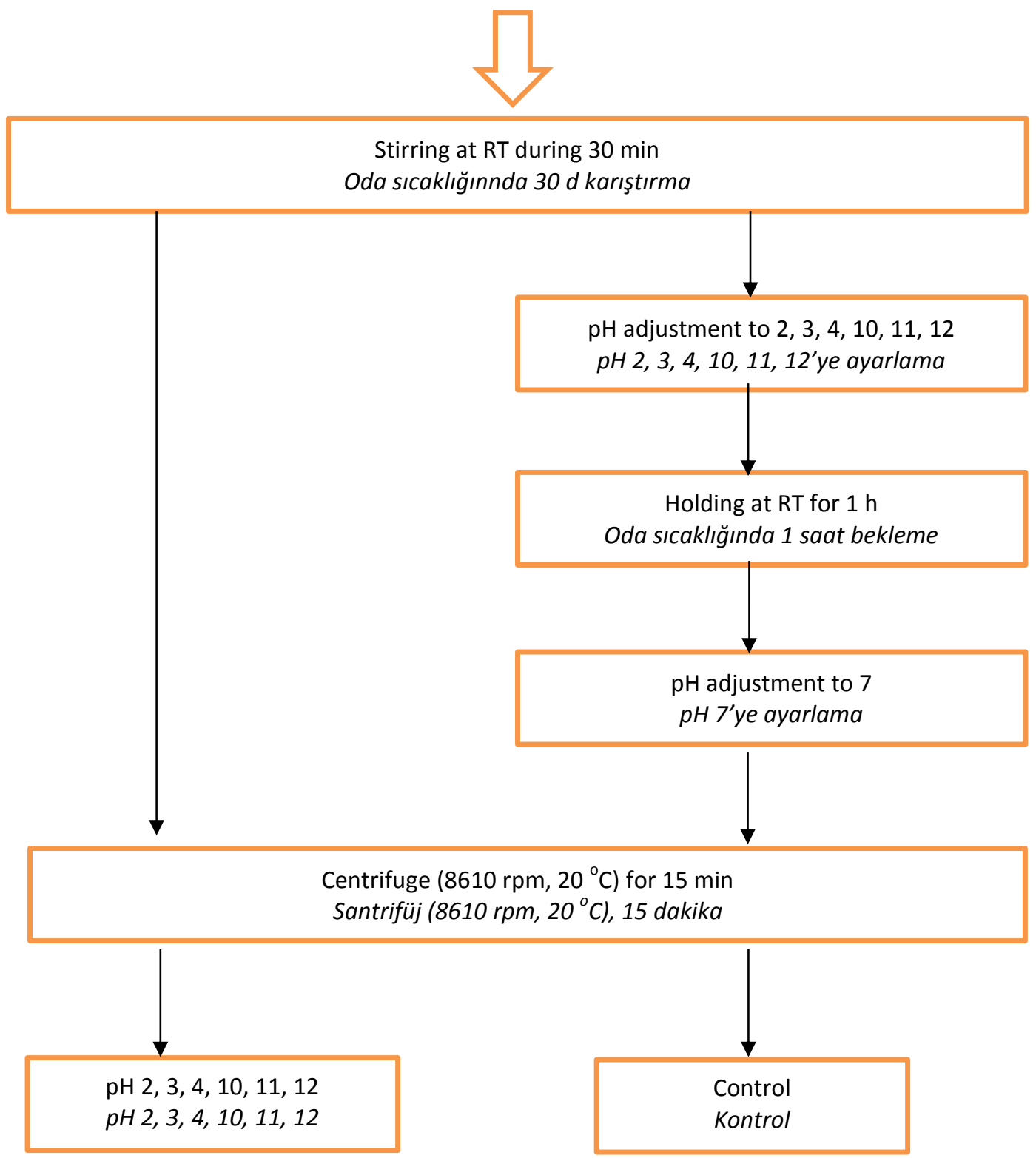

Figure 1. Preparation of soy protein concentrate samples Şekil 1. Soy protein konsantre örneklerinin hazırlanışı

\section{Particle size and turbidity}

Particle sizes of the SPC samples were determined by dynamic light scattering (DLS) using a NICOMP 380 DLS instrument. Samples were diluted 500 -fold with DI water before the measurement. All measurements were performed at RT. The average of 3 runs was used to calculate particle size $(\mathrm{nm})$.

Turbidity of the SPC solutions was determined with a spectrophotometer according to the method proposed by Yildiz et al. (2017). DI water was used as the blank, and the absorbance at 600 $\mathrm{nm}$ was read.

\section{Emulsifying properties}

Emulsifying activity index (EAI) and emulsion stability index (ESI) were calculated by following the method of Pearce et al. (1979). Firstly, the 
emulsions were prepared by mixing $1 \mathrm{~mL}$ of canola oil and $3 \mathrm{~mL}$ of the SPC samples. The blend of oil and SPC solution was stirred vigorously during $5 \mathrm{~min}$. Then, the absorbance was measured at $500 \mathrm{~nm}$ at $0\left(A_{0}\right)$ and $10 \mathrm{~min}\left(A_{10}\right)$. EAI and ESI were calculated according to the below formula:

$E A I\left(m^{2} g^{-1}\right)=2 T A_{0} \times$ dilution factor $/ c \times \Phi \times L \times 10000$

$E S I(\min )=A_{0} /\left(A_{0}-A_{10}\right) \times 10(\mathrm{~min})$

where $\mathrm{T}$ : 2.303; dilution factor: 100 , c: weight of protein per unit volume $\left(\mathrm{g} \mathrm{mL}^{-1}\right)$, L: width of the optical path $(0.01 \mathrm{~m})$, and $\Phi$ : oil volumetric fraction

\section{Statistical Analysis}

The differences were determined by using the General Linear Models procedure in SAS program. Significant differences among the means were identified with Fisher's least significant difference (LSD) test at alpha $=0.05$.

\section{Results and Discussion}

Table 2 presents the protein solubility values of the SPC samples were treated by different $\mathrm{pH}$ values. The highest protein solubility was observed $61.1 \%$ for the $\mathrm{pH} 12$ treatment, whereas the lowest protein solubility (1.93\%) was observed in the untreated SPC. Principally, different $\mathrm{pH}$ treatments had no improvement on the solubility, except at $\mathrm{pH} 12$ treatment. There is a slight difference between the untreated SPC and other $\mathrm{pH}$ treatments $(\mathrm{pH} 2,3,4,10$, and 11). Under the alkaline conditions, SPC samples showed a slightly higher solubility compared to the acidic conditions. While the SPC solubility was found as $3.51 \%, 3.78 \%$, and $61.1 \%$ for the $\mathrm{pH} 10$, $\mathrm{pH} \mathrm{11}$, and $\mathrm{pH} 12$ treatments subsequently, the SPC solubility was observed as $2.85 \%, 2.98 \%$, and $2.08 \%$ for the $\mathrm{pH} \mathrm{2,} \mathrm{pH} 3$, and $\mathrm{pH} 4$, subsequently (Table 2). A significant increase in soy protein solubility with a pH treatment was stated previously. Lee et al. (2016) stated that the solubility of the soy protein isolate (SPI) samples showed a significant increase by $\mathrm{pH} 12$ treatment. It was stated that the $\mathrm{pH} 12$-treated SPI increased the solubility from $1.49 \%$ to $67.34 \%$, which is slightly higher than the solubility (61.1\%) found in this study. This change might be caused by the different soy protein products used in these studies. The purest type of soy protein called as SPI with $90 \%$ protein on dry basis was used in the work of Lee et al. (2016). In addition, Yildiz et al. (2017) found that $\mathrm{pH}$ 12-treated soy protein showed a significant higher protein solubility (57.0\%) compared to the untreated SPI samples (9.1\%). Similar results of $\mathrm{pH}$ shifting method were also pronounced in several studies using different kinds of plant proteins rather than soy protein. For example, a significant increase of pea protein solubility treated with $\mathrm{pH} 12$ was achieved in the study of Jiang et al. (2017). It was observed that $\mathrm{pH} 12$ treated pea protein isolate (PPI) increased PPI solubility from $8.17 \%$ for the control to 54.94 $\%$ (Jiang et al., 2017). Environmental factors including $\mathrm{pH}$, temperature, and ionic strength have an effect on protein solubility (Bolontrande et al., 2013). Jiang et al. (2009) announced that supposing the proteins to extreme $\mathrm{pH}$ conditions (i.e, $\mathrm{pH} 12$ or $\mathrm{pH} 2$ ) caused a partial unfolding of proteins. The $\mathrm{pH}$ is after that adjusted back to $\mathrm{pH}$ 7 to refold the protein. This unfolding-refolding phenomena was described as an effective step in modification of protein characteristics (Jiang et al., 2010; Yildiz et al., 2017). Therefore, the increase in SPC solubility might be because of the increase of ionic relationship between the proteins and water.

Ho values of the SPC samples are shown in Table 2. The lowest surface hydrophobicity (127.0) was observed for the untreated SPC. On the other hand, the highest Ho (215.0) was observed for the $\mathrm{pH}$ 12-treated SPC dispersions. Among all different $\mathrm{pH}$ treatments, only the $\mathrm{pH} 12$ treatment significantly increased the protein Ho up to 215.0 (Table 2). There is not any significant changes was observed between the untreated SPC and other $\mathrm{pH}$ - shifting $(\mathrm{pH} 2,3,4,10$, and 11) treated samples. The significantly higher Ho of the $\mathrm{pH}$ 12-treated SPC samples showed a more 
severe modification of SPC structure in comparison with the other treatments. A positive relationship was observed between the solubility and Ho (Table 2). For example, the $\mathrm{pH} 12$ treated samples had the highest solubility (61.1\%) with the highest Ho (215.0). In a similar way, the untreated SPC had the lowest solubility (1.93\%), and its Ho (127.0) was also the lowest. $\mathrm{pH}$ treatment may lead to the exposure of hydrophobic groups initially buried in the interior of the protein molecules. Dissociation of native protein structures into individual subunits is thought to be the driving force for the increased solubility. This finding is in agreement with the observation of Yildiz et al. (2017) who found also a positive relationship between solubility and Ho of SPI. Furthermore, the confirmation of this was shown in the work of Lee et al. (2016) and Jiang et al (2017). Both Ho and solubility are the known as major factors which affects the emulsifying activity of a protein (Jiang et al., 2011). Good emulsifying and foaming ability related to the balance between hydrophilic and hydrophobic groups (Jambrak et al., 2008). The $\mathrm{pH}$ 12-treated SPC exhibited both high solubility and increased Ho, which is the indicator of better emulsifying capacity and stability.

Free sulfhydryl groups (SH) of the SPC samples are presented in Table 2. The free SH contents of the $\mathrm{pH}$ 12-treated SPC were found as the highest among all other treatments $\left(5.17 \mu \mathrm{mol} \mathrm{g}{ }^{-1}\right)$. The lowest $\mathrm{SH}$ content was found for the untreated SPC (3.89 $\left.\mu \mathrm{mol} \mathrm{g}^{-1}\right)$. No significant differences were detected between the untreated SPC and

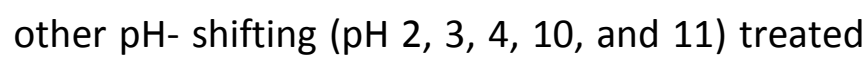
samples (Table 2). Free SH content is important parameter for protein functionality, since it has a significant effect on both denaturation and oxidation. A higher $\mathrm{SH}$ content shows mainly exposure of internal $\mathrm{SH}$ groups because of the protein unfolding caused by $\mathrm{pH}$-shifting. Hence, the surface $\mathrm{SH}$ content is related to conformation changes and protein unfolding (Jiang et al., 2017). The increase in free $\mathrm{SH}$ content could also be caused by decrease SPC particle sizes after $\mathrm{pH}$ shifting treatment, which allows the buried $\mathrm{SH}$ groups in SPC to be supposed to the surface. The higher $\mathrm{SH}$ in the $\mathrm{pH}$ 12-treated SPC rather than the other $\mathrm{pH}$ treatments showed the advantage of $\mathrm{pH} 12$ treatment. The improvement of free $\mathrm{SH}$ content was also expressed by Lee et al. (2016) and Yildiz et al. (2017) in the $\mathrm{pH} 12$ treated soy protein samples compared to the control. From Table 2, the $\mathrm{pH} 12$ treated SPC samples showed the highest protein solubility (61.1\%) which shows the increase in $\mathrm{SH}$ content lead to higher solubility.

Table 2. Physicochemical properties of the untreated (control) and the treated SPC samples Çizelge 2. Kontrol ve muamelegGörmüş soy protein konsantre örneklerinin fizikokimyasal özellikleri

\begin{tabular}{|l|c|c|c|}
\hline $\begin{array}{l}\text { Treatments } \\
\text { Yöntemler }\end{array}$ & $\begin{array}{c}\text { Solubility (\%) } \\
\text { Çözünürlük }\end{array}$ & $\begin{array}{c}\text { Surface hydrophobicity }\left(\mathrm{H}_{0}\right) \\
\text { Yüzey hidrofobikliği }\end{array}$ & $\begin{array}{c}\text { Free SH }\left(\mu \mathrm{mol} \mathrm{g}^{-1}\right) \\
\text { Bağımsız sülfidril topluluğu }\end{array}$ \\
\hline Control & $1.93+0.2^{\mathrm{b}}$ & $127+0.8^{\mathrm{b}}$ & $3.89+0.13^{\mathrm{b}}$ \\
\hline $\mathrm{pH}$-shifting $(\mathrm{pH} \mathrm{2)}$ & $2.85+0.7^{\mathrm{b}}$ & $128+0.3^{\mathrm{b}}$ & $4.03+0.07^{\mathrm{b}}$ \\
\hline $\mathrm{pH}$-shifting $(\mathrm{pH} \mathrm{3)}$ & $2.98+0.6^{\mathrm{b}}$ & $125+0.7^{\mathrm{b}}$ & $4.02+0.24^{\mathrm{b}}$ \\
\hline $\mathrm{pH}$-shifting $(\mathrm{pH} \mathrm{4)}$ & $2.08+1.2^{\mathrm{b}}$ & $112+0.5^{\mathrm{b}}$ & $3.95+0.11^{\mathrm{b}}$ \\
\hline $\mathrm{pH}$-shifting $(\mathrm{pH} \mathrm{10)}$ & $3.51+1.5^{\mathrm{b}}$ & $118+0.2^{\mathrm{b}}$ & $4.08+0.18^{\mathrm{b}}$ \\
\hline $\mathrm{pH}$-shifting $(\mathrm{pH} \mathrm{11)}$ & $3.78+0.9^{\mathrm{b}}$ & $125+0.6^{\mathrm{b}}$ & $4.11+0.15^{\mathrm{b}}$ \\
\hline $\mathrm{pH}$-shifting $(\mathrm{pH} \mathrm{12)}$ & $61.1+1.1^{\mathrm{a}}$ & $215+0.5^{\mathrm{a}}$ & $5.17+0.08^{\mathrm{a}}$ \\
\hline
\end{tabular}

${ }^{a-b}$ Mean \pm standard deviation $(n=3)$ of samples with the same letter are not significantly different $(p<0.05)$

*All the statistics were done separately for each parameters (solubility, surface hydrophobicity, and free $\mathrm{SH}$ )

${ }^{a-b}$ Aynı harfle gösterilen değerler istatistiksel olarak farklı değildir $(p<0.05)$

*istatistik analizi her bir parametre için (çözünürlük, yüzey hidrofobikliği, ve bağımsız sülfidril topluluğu)

Table 3 shows the EAI and ESI of SPC treated with different $\mathrm{pH}$ values. It was found that the $\mathrm{pH}$ 12-treated samples resulted with the highest EAI $\left(218 \mathrm{~m}^{2} \mathrm{~g}^{-1}\right)$ and ESI $(36.0 \mathrm{~min})$, while the untreated SPC showed the lowest EAI $\left(88 \mathrm{~m}^{2} \mathrm{~g}^{-1}\right)$ and ESI (18.0 $\mathrm{min})$. Similar improvement in the emulsifying characteristics of soy proteins with a $\mathrm{pH}$-shifting treatment was pointed out in the 
reports of Jiang et al. (2009) and Yildiz et al. (2017).Specifically, emulsifying properties are related to both protein solubility and Ho (Zhang et al., 2014). It is possible to see this relationship by comparing Table 2 and Table 3. Basically, the SPC samples with high solubility and Ho, namely pH 12-treated samples, also had high ESI and EAI. In overall, the use of $\mathrm{pH}$-shifting treatment, especially $\mathrm{pH}$ 12-treatment, was resulted with an improvement in physicochemical properties (solubility, Ho, etc.) and emulsifying properties (ESI and EAI).

The DLS measurement of the soluble SPC with the 6 different $\mathrm{pH}$-treatments are presented in Table 3. $\mathrm{pH}$ 12-treatment produced soluble SPC aggregates with sizes of $<100 \mathrm{~nm}(65.3 \mathrm{~nm})$. The $\mathrm{pH}$ 12-treated sample was resulted with a smallest size $(65.3 \mathrm{~nm})$, whereas the size for the untreated SPC was $251.4 \mathrm{~nm}$. In addition, there was a slight decrease in particle size of other $\mathrm{pH}$ treatments compared to the untreated SPC samples

was observed (Table 3 ). The unfolding process especially by high $\mathrm{pH}$ treatment $(\mathrm{pH} 12)$ may cause SPC samples to become more susceptible to break-down. The decrease in the particle size of plant proteins (i.e., soy protein, and pea protein) was reported in previous studies (Lee et al., 2016; Jiang et al., 2017; Yildiz et al., 2017).

The turbidity results of SPC samples are tabulated in Table 3. The $\mathrm{pH}$ 12-treated SPC achieved the highest solubility. On the other hand, they showed the smallest particle sizes $(65.3 \mathrm{~nm})$. Therefore, their turbidity was found as the lowest (0.09) among the treatments. Moreover, the largest particle sizes $(251.4 \mathrm{~nm}$ ) with the highest turbidity (Table 3 ) was observed for the untreated SPC.

Table 3. Emulsifying properties (EAI, ESI, particle size and turbidity) of the untreated and treated SPC samples

Çizelge 3. Kontrol ve muamele görmüş soy protein konsantre örneklerinin emülsiyon özellikleri (emülsiyon aktivite indeksi, emülsiyon stabilite indeksi, parçacık boyutu ve bulanıklık)

\begin{tabular}{|l|l|l|l|l|}
\hline $\begin{array}{l}\text { Treatments } \\
\text { Yöntemler }\end{array}$ & $\begin{array}{l}\text { EAI }\left(\mathrm{m}^{2} \mathrm{~g}^{-1}\right) \\
\text { Emülsiyon Aktivite } \\
\text { Indeksi }\left(\mathrm{m}^{2} \mathrm{~g}^{-1}\right)\end{array}$ & $\begin{array}{l}\text { ESI (min) } \\
\text { Emülsiyon Stabilite Indeksi } \\
\text { (dakika) }\end{array}$ & $\begin{array}{l}\text { Particle size (nm) } \\
\text { Parçacık boyutu (nm) }\end{array}$ & $\begin{array}{l}\text { Turbidity } \\
\text { Bulanıklık }\end{array}$ \\
\hline Control & $88+1.2^{\mathrm{c}}$ & $18.0^{\mathrm{c}}$ & $251.4+1.3^{\mathrm{a}}$ & $0.24+0.3^{\mathrm{a}}$ \\
\hline $\mathrm{pH}$-shifting (pH 2) & $111+1.7^{\mathrm{b}}$ & $25.0^{\mathrm{b}}$ & $218.7+1.2^{\mathrm{b}}$ & $0.15+0.1^{\mathrm{b}}$ \\
\hline $\mathrm{pH}$-shifting (pH 3) & $108+2.3^{\mathrm{b}}$ & $26.0^{\mathrm{b}}$ & $221.5+1.2^{\mathrm{b}}$ & $0.15+0.1^{\mathrm{b}}$ \\
\hline $\mathrm{pH}$-shifting (pH 4) & $105+2.1^{\mathrm{b}}$ & $22.0^{\mathrm{b}}$ & $248.5+1.1^{\mathrm{a}}$ & $0.17+0.2^{\mathrm{b}}$ \\
\hline $\mathrm{pH}$-shifting (pH 10) & $118+1.8^{\mathrm{b}}$ & $23.0^{\mathrm{b}}$ & $213.5+1.7^{\mathrm{b}}$ & $0.17+0.1^{\mathrm{b}}$ \\
\hline $\mathrm{pH}$-shifting (pH 11) & $115+1.6^{\mathrm{b}}$ & $24.0^{\mathrm{b}}$ & $212.8+1.5^{\mathrm{b}}$ & $0.18+0.3^{\mathrm{b}}$ \\
\hline $\mathrm{pH}$-shifting (pH 12) & $218+1.6^{\mathrm{a}}$ & $36.0^{\mathrm{a}}$ & $65.3+1.3^{\mathrm{c}}$ & $0.09+0.2^{\mathrm{c}}$ \\
\hline
\end{tabular}

${ }^{a-c}$ Mean \pm standard deviation $(n=3)$ of samples with the same letter are not significantly different $(p<0.05)$

*All the statistics were done separately for each parameters (ESI, EAI, particle size, and turbidity)

${ }^{\mathrm{a}-\mathrm{c}}$ Aynı harfle gösterilen değerler istatistiksel olarak farklı değildir $(p<0.05)$

*istatistik analizi her bir parametre için (ESI, EAI, parçacık boyutu, and bulanıklık)

\section{Conclusion}

A chemical treatment, $\mathrm{pH}$-shifting process was examined for the purpose of modification and enhancement of the soy protein functionality. Compared with other $\mathrm{pH}$-treatments, a significant improvement in the physicochemical (solubility, free $\mathrm{SH}$, and, surface hydrophobicity), and emulsifying (particle size, EAI, and ESI) properties of SPC samples was achieved with a $\mathrm{pH} 12$ treatment. The results of current study showed the potential of the $\mathrm{pH} 12$ treatment as an effective chemical method for protein modification.

\section{References}

Bolontrade, A. J., Scilingo, A. A., \& Anon, M.C. (2013). Amaranth proteins foaming properties: Adsorption kinetics and foam formation-Part 1. Colloids and Surfaces B: Biointerfaces, 105, 319-327.

Bradford, M.M. (1976). A rapid and sensitive method for the 
quantitation of microgram quantities of protein utilizing the principle of protein-dye binding. Analytical Biochemistry, 72, 248-254.

Campbell, M.F., Kraut, C.W., Yackel, W.C., \& Yang, H.S. (1985). Soy Protein Concentrate, in New Protein Foods. Altschul and Wilke Eds. Vol. 5, p 301.

Choi, J.Y., \& Kim, J. (2005). Fish protein recovered using pH shifting method and its physicochemical properties. Journal of Ocean University of China, 4(3), 224-228.

Elizalde, B.E., Bartholomai, G.B., \& Pilosof, A.M.R. (1996). The effect of $\mathrm{pH}$ on the relationship between hydrophilic/lipophilic characteristics and emulsification properties of soy proteins. LWT-Food Science and Technology, 29, 334-339.

Goto, Y. (1989). Conformational states of ß-lactamase: Molten-globule states at acidic and alkaline $\mathrm{pH}$ with high salt. Biochemistry, 28(3), 945-952.

Goto, Y., Calciano, L. J., \& Fink, A. L. (1990). Acid-induced folding of proteins. Proceedings of National Academy of Sciences of the United States, 87, 573-577.

$\mathrm{Hu}, \mathrm{H}$. , Wu, J., Li-Chan, E.C.Y., Zhu, L., Zhang, F., Xu, X., Fan, G., Wang, L., Huang, X., \& Pan, S. (2013). Effects of ultrasound on structural and physical properties of soy protein isolate (SPI) dispersions. Food Hydrocolloids, 30 (2), 647-655.

Jambrak, A., Mason, T., Lelas, V., Herceg, Z., \& Herceg, I. (2008). Effect of ultrasound treatment on solubility and foaming properties of whey protein suspensions. Journal of Food Engineering, 86 (2), 281-287.

Jiang, J., Chen, j., \& Xiong, Y.L. (2009). Structural and emulsifying properties of soy protein isolate subjected to acid and alkaline $\mathrm{pH}$-shifting processes. Journal of Agricultural and Food Chemistry, 57 (16), 7576-7583.

Jiang, J., Xiong, Y.L., \& Chen, J. (2010). pH shifting alters solubility characteristics and thermal stability of soy protein isolate and its globulin fractions in different $\mathrm{pH}$, salt concentration, and temperature conditions. Journal of Agricultural and Food Chemistry, 58 (13), 8035-8042.

Jiang, J., Xiong, Y.L., \& Chen, J. (2011). Role of ß-conglycinin and glycinin subunits in the $\mathrm{pH}$-shifting-induced structural and physicochemical changes of soy protein isolate. Journal of Food Science, 76 (2), 293302.

Jiang, J., Zhu, B., Liu, Y., \& Xiong, Y. (2014). Interfacial structural role of $\mathrm{pH}$-shifting processed pea protein in the oxidative stability of Oil/Water emulsions. Journal of Agricultural and Food Chemistry, 62(7), 1683-1691.

Kristinsson, H.G., \& Hultin, H.O. (2003). Changes in conformation and subunit assembly of cod myosin at low and high $\mathrm{pH}$ and after subsequent refolding. Journal of Agricultural Food Chemistry, 51, 71877196.

Kristinsson, H. G., \& Hultin, H.O. (2004). Changes in trout hemoglobin conformations and solubility after exposure to acid and alkali $\mathrm{pH}$. Journal of Agricultural Food Chemistry, 52, 3633-3643.
Lee, H., Yildiz, G., Dos Santos, L.C., Jiang, S., Andrade, J., Engeseth, N.C., \& Feng, H. (2016). Soy protein nanoaggregates with improved functional properties prepared by sequential $\mathrm{pH}$ treatment and ultrasonication. Food Hydrocolloids, 55, 200-209.

Li, Y., Chen, Z., \& Mo, H. (2007). Effects of pulsed electric fields on physicochemical properties of soybean protein isolates. LWT-Food Science and Technology, 40, 1167-1175.

Liang, Y., \& Kristinsson, H. G. (2007). Structural and foaming properties of egg albumen subjected to different $\mathrm{pH}$ treatments in the presence of calcium ions. Food Research International, 40, 668-678.

Manassero, C.A., Vaudagna, S.R., Anon, M.C., \& Speroni, F. (2015). High hydrostatic pressure improves protein solubility and dispersion stability of mineral-added soybean protein isolate. Food Hydrocolloids, 43, 629635.

Molina, E., Papadopoulou, A., \& Ledward, D.A. (2001). Emulsifying properties of high pressure treated soy protein isolate and $7 \mathrm{~S}$ and $11 \mathrm{~S}$ globulins. Food Hydrocolloids, 15, 263-269.

Palazolo, G., Sorgentini, D., \& Wagner, J. (2005). Coalescence and flocculation in o/w emulsions of native and denatured whey soy proteins in comparison with soy protein isolates. Food Hydrocolloids, 19(3), 595-604.

Pearce, K.N., \& Kinsella, J.E. (1979). Emulsifying properties of proteins: evaluation of a turbidimetric technique. Journal of Agricultural and Food Chemistry, 26, 716723.

Puppo, M.C., Speroni, F., Chapleau, N., De LamballerieAnton, M., Anon, M.C., \& Anton, M. (2005). Effect of high-pressure treatment on emulsifying properties of soybean proteins. Food Hydrocolloids, 19, 289-296.

Santiago, L., Gonzalez, R., Remondetto, G., \& Bonaldo, A. (1998). Emulsifying ability of proteins evaluated by response surface methodology. Food Science and Technology-Lebensmittel-Wissenschaft \& Technologie, 31(3), 259-264.

Tsumura, K., Saito, T., Tsuge, K., Ashida, H., Kugimiya, W., \& Inouye, K. (2005). Functional properties of soy protein hydrolysates obtained by selective proteolysis. LWT-Food Science and Technology, 38, 255-261.

Yildiz, G., Andrade, J., Engeseth, N.C., \& Feng, H. (2017). Functionalizing soy protein nano-aggregates with $\mathrm{pH}$ shifting and mano-thermo-sonication. Journal of Colloid and Interface Science, 505, 836-846.

Zhang, Q., Tu, Z., Xiao, H., Wang, H., Huang, X., Liu, G., Liu, C., Shi, Y., Fan, L., \& Lin, D. (2014). Influence of ultrasonic treatment on the structure and emulsifying properties of peanut protein isolate. Food and Bioproducts Processing, 92, 30-37.

Zhang, Q., Tu, Z., Wang, H., Huang, X., Fan, Z.L., Bao, H., \& Xiao, H. (2015). Functional properties and structure changes of soybean protein isolate after subcritical water treatment. Journal of Food Science and Technology, 52, 3412-3421. 